\title{
A value chain analysis of Malaysia's seaweed industry
}

\author{
Adibi M. Nor ${ }^{1,3}\left(\mathbb{D} \cdot \operatorname{Tim}\right.$ S. Gray ${ }^{2} \cdot$ Gary S. Caldwell $^{3} \cdot$ Selina M. Stead ${ }^{4}$
}

Received: 25 July 2019 / Revised and accepted: 14 October 2019 / Published online: 27 December 2019

(C) The Author(s) 2019

\begin{abstract}
A global shortfall in protein supply from capture fisheries has motivated the Malaysian government to revise its aquaculture strategy, focusing on three commodities: seaweed, fish and marine shrimp. However, the performance of the Malaysian aquaculture sector, particularly seaweed production, is poorly documented. This is the first empirical study to undertake a value chain analysis (VCA) of the Malaysian seaweed sector using stakeholder perceptions and secondary data that encompass members of seaweed farming cooperatives (the Semporna Area Farmers' Association and the governments' flagship Seaweed Cluster Project). Fieldwork was conducted between April and June 2015 among seaweed stakeholders involved in the value chain using a mixed methods approach - in-depth interviews with key informants, focus group discussions, household surveys, personal observation and secondary data. Qualitative and quantitative data were collected from both upstream (seaweed farming, marketing structure and the Malaysian Good Aquaculture Practices [MyGAP] certification programme) and downstream (seaweed processing) activities involving farmers, intermediaries/middlemen (buyers), processors and officials. Kappaphycus spp. was sold in two forms: (1) dried seaweed to be used as raw materials in carrageenan processing (approximately $90 \%$ of total harvest) and (2) fresh seaweed to be used as a source of seedlings (approximately $10 \%$ of total harvest). The value chain ended with the carrageenan form, which is exported to international markets. The price of dried seaweed varied according to a combination of seaweed quality, the strength of farmer's relationships with intermediaries and processors and in response to demand from the carrageenan industry. The prices obtained by Malaysian farmers for dried seaweed and carrageenan remained low, US\$0.60 and US\$ 4.43 per kg, respectively, despite efforts by the government to enhance the value chain by imposing seaweed standards (via MyGAP) for farm management, dried seaweed and semi-refined carrageenan. The VCA was a useful tool to identify and map the market, with the results providing a better understanding of the seaweed sector, which could be helpful in supporting further aquaculture development in Malaysia.
\end{abstract}

Keywords Value chain analysis (VCA) $\cdot$ Kappaphycus $\cdot$ Food security $\cdot$ Macroalgae $\cdot$ Malaysia $\cdot$ Seaweed aquaculture

\section{Introduction}

Global fish consumption from capture fishing and aquaculture exceeded $20.5 \mathrm{~kg}$ per capita in 2017 (FAO 2016). Malaysia is

Adibi M. Nor

adibi@um.edu.my

1 International Institute of Public Policy and Management, University of Malaya, 50603 Kuala Lumpur, Malaysia

2 School of Geography, Politics and Sociology, Newcastle University, Newcastle upon Tyne NE1 7RU, UK

3 School of Natural and Environmental Sciences, Newcastle University, Ridley Building 2, Newcastle upon Tyne NE1 7RU, UK

4 Institute of Aquaculture, Faculty of Natural Sciences, University of Stirling, StirlingStirlingshire, FK9 4LA, Scotland the third major fish-consuming country in Asia after Japan and South Korea. Malaysia people consumed more than $50 \mathrm{~kg}$ per capita in 2015 and is projected to reach $64 \mathrm{~kg}$ per capita in 2020 (Teh 2012). The Malaysia fisheries sector, including both capture fisheries and aquaculture, produced 1.48 million $\mathrm{t}$ and $397,000 \mathrm{t}$ in 2018 , respectively, with macroalgae (seaweed) the major aquaculture contributor $(31 \%$ of total production by weight in 2018). Furthermore, seaweed farming brings added value by contributing to socioeconomic development by enhancing household incomes (Sievanen et al. 2005; Bjerregaard et al. 2016; Siew-Moi et al. 2017; Phang et al. 2019). The bulk of Malaysian seaweed is produced in Eastern Malaysia (Semporna district, Sabah), primarily for carrageenan extraction - a hydrocolloid derived from red seaweed which is used in food, dairy products and pharmaceuticals (Li et al. 2014; Prajapati et al. 2014). The increased demand for processed foods in the USA and Europe has 
contributed to the recent growth of the carrageenan industry (Ferdouse et al. 2018). For instance, the annual growth rate of global carrageenan was $2 \%$ between 2009 and 2015, which was then valued at more than half a US billion dollars (Porse and Rudolph 2017). The top five major producers of seaweed carrageenan (13.0 million $\mathrm{t}$ wet weight or 1.3 million $\mathrm{t}$ dry weight in 2016) were Indonesia, the Philippines, Malaysia, United Republic of Tanzania and Vietnam (FAO, 2018).

The Malaysian government, via the Malaysian seaweed development plan (administered through the Department of Fisheries Malaysia (DOFM)), intends seaweed aquaculture to play increasingly significant roles in ensuring food security, reducing pressure from capture fisheries, generating foreign exchange income, providing employment, extending alternative livelihoods and creating opportunities for business and commercial investment (Wood and Davies 2006; PEMANDU 2013). However, notwithstanding the fact that Malaysia is the third largest global seaweed carrageenan producer (20,297 t of dried seaweed in 2016 (DOFM 2019)), its seaweed sector is understudied and poorly understood and is hindered by ethnic tensions between immigrant and indigenous farmers. The commercially farmed seaweed in Sabah is predominantly Kappaphycus alvarezii and Kappaphycus striatum, both commercially known as 'cottonii'. Farmers also plant Eucheuma denticulatum (known commercially as 'spinosum') depending on demand from buyers or processors. The increased demand for seaweed and its derivatives affords Malaysia an opportunity to further develop its position as a major global producer, with the DOFM projecting production to reach $150,000 \mathrm{t}$ of dried seaweed, or more than half of global demand, by 2020 based on the availability of potential farming sites - 40,500 ha (PEMANDU, 2013). The continued development of seaweed farming cooperatives (e.g. the Semporna Area Farmers' Association (SAFA) and the governments' flagship Seaweed Cluster Project (SCP)) have been identified as key mechanisms to achieve this growth target, but with limited success (Nor et al. 2017). This paper, a follow-up to the study by Nor and co-workers (Nor et al. 2017), presents a value chain analysis (VCA) of the Malaysian seaweed aquaculture sector (completed in 2015) with the objective to focus on its governance, economic, environmental, technological and sociocultural dimensions, identifying the main problems it faces in meeting the government's production target and outlining possible solutions.

\section{Conceptual framework-VCA}

Value chain analysis (VCA) is a useful tool to assess the commercial viability of seaweed aquaculture with similar approaches having been applied to the Indonesian and Philippines industries (Neish 2008, 2013; Andriesse and Lee 2017; Ferdinandus et al. 2017; Mulyati and Geldermann
2017). A value chain denotes a list of activities that a firm carries out to produce a product or service for a given market. A VCA may be internal to a firm, when its aim is to identify which activities are the most valuable and which ones could be improved upon to increase competitiveness. Or, as in the case of the Malaysian seaweed industry, VCA can be used as a means of financial accounting of all the links in the chain between the production of a good and its consumption, recycling or disposal. The objective of carrying out such a VCA is to identify the points where the product may be inefficiently passed on and the producer may be losing an opportunity to maximise market uptake. Capturing the value generated along the chain is only possible if the value at each link of the chain is known.

The seaweed carrageenan value chain can be categorised into upstream and downstream activities (Fig. 1). Upstream activities encompass the farming stages, e.g. seeding, maintenance, harvesting and initial postharvest treatment (drying and packing). A full farming cycle requires at least 45 days. The farmers will determine whether the harvested seaweed will be sent for drying or seeding purposes. Matured seaweed is usually dried, whereas young seaweeds are kept as seedlings. Drying takes 3 to 7 days depending on the weather and size of the drying facilities. Downstream activities comprise marketing, trading and transportation before terminating with carrageenan extraction. The marketing value chain uses seaweed in two forms: (1) fresh seaweed is used as a source of seedlings or propagules, and (2) dried seaweed is used as raw materials in carrageenan extraction. The dried seaweed is sold to intermediaries or processors, and finally carrageenan is produced and exported to international markets.

Carrageenan is separated into refined carrageenan (RC) or semi-refined carrageenan (SRC) depending on the processing method. RC production is more expensive as it involves carrageenan extraction using complex processing with high operating costs, e.g. water treatment, energy and chemicals. SRC processing is cheaper as carrageenan is not extracted; rather gel strength is enhanced by alkaline treatment. The leftover carrageenan or residue, which has a similar appearance to seaweed, is dried, milled and blended into SRC (McHugh 2003). Any unmilled residue is called alkali treated 'cottonii' or alkali treated chips (ATC). ATC benefits the RC processors due to cheaper transportation costs compared with importing dried seaweed and reduced waste management costs. SRC is categorised by food grade, e.g. Philippine Natural Grade (PNG) or Processed Eucheuma Seaweed (PES), and nonfood grade, e.g. seaweed flour (McHugh 2003). The dried seaweed is processed into several products (SRC and RC) before being sold to the processed food industry. According to Panlibuton et al. (2007), the average export price for dried 'cottonii' and 'spinosum' ranges from 
Fig. 1 Overview of the seaweed carrageenan value chain
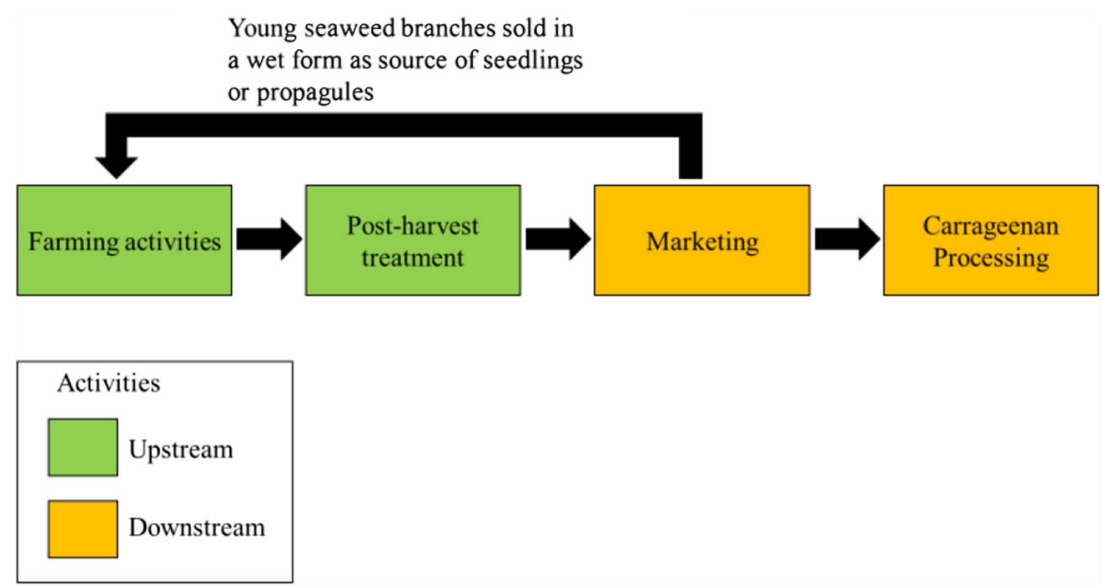

US $\$ 0.69$ to US $\$ 1.20$ per $\mathrm{kg}$ depending on the quality, increasing to US $\$ 3.50$ to US $\$ 5.50$ per $\mathrm{kg}$ once processed into SRC. The value of seaweed carrageenan increases to US\$9 per kg after RC production (gel pressing method). The final step in the value chain is the production of RC (alcohol precipitation method), which could fetch a maximum value of US\$30 per kg (Fig. 2).

\section{Methods}

\section{Ethics statement}

This study received ethical approval from the Newcastle University Ethics Committee. Additional permissions were granted by the Malaysian government (Economic Planning Unit, Prime Minister's Department).

\section{Data collection}

The data obtained to understand the VCA of seaweed production in Malaysia came from stakeholders, personal observation and secondary sources. The stakeholders included 42 key informant interviewees (KIs), 40 focus group discussants (FGDs) and 144 household survey questionnaire respondents (SQs). The KIs were conducted with government officials, nongovernmental organisation (NGO) representatives, community leaders and private companies, selected using nonprobability sampling through the snowball method (this approach was appropriate to identify the KIs involved in the seaweed value chain). The FGDs and the SQs were recruited from seven islands and villages in Semporna districts in the state of Sabah (Table 1; see Nor et al. (2017) for further details). Sabah, the only Malaysian state producing seaweed on a commercial scale, was chosen as the study site. The main seaweed-producing areas in Sabah are Semporna, Tawau,
Fig 2 Seaweed carrageenan value chain and export prices

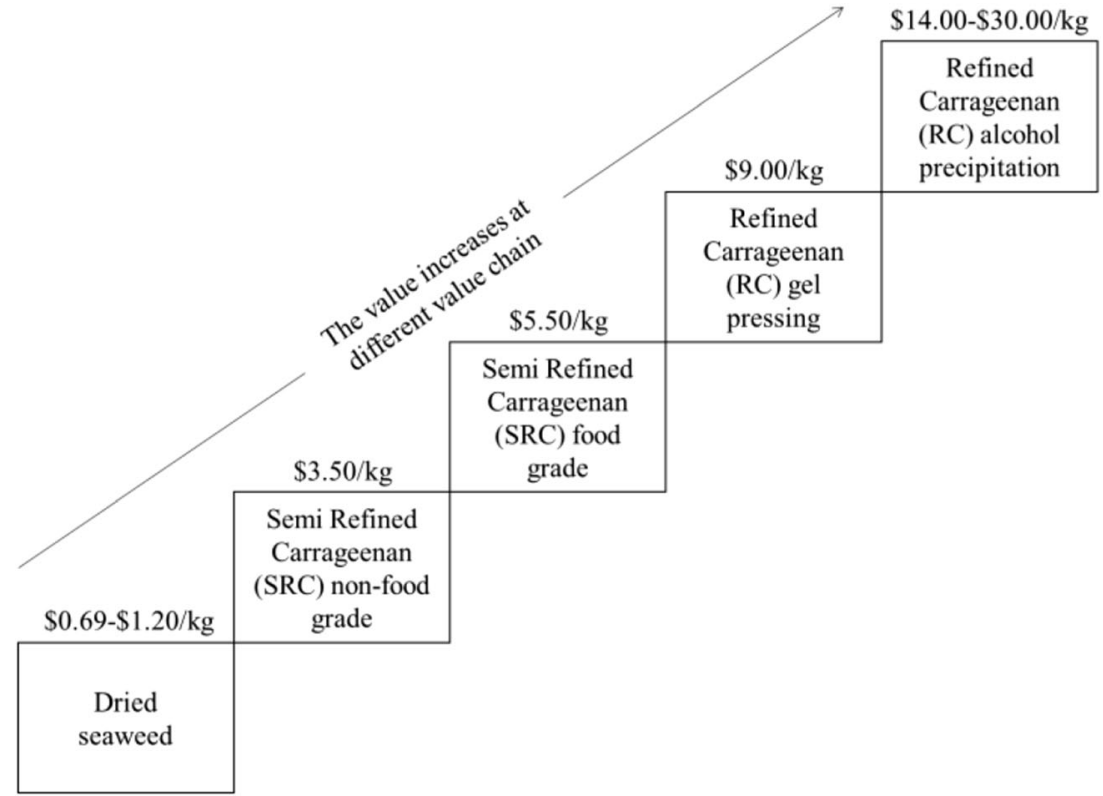


Table 1 Description of the study sites in relation to the type of farmers and geographical location. For further details, see Nor et al. (2017)

\begin{tabular}{lll}
\hline Study sites & Type of farmers & Geographical location \\
\hline Look Butun & SCP Cooperative & North \\
Gelam-gelam & SCP Cooperative & North \\
Patuit a and b & Migrant & East \\
Sebangkat a and b & Migrant & East \\
Mata Pahi/Melanta Kobal & SAFA Cooperative & West \\
Palang-palang & Migrant & South \\
Sangaban a and b & Migrant & South \\
\hline
\end{tabular}

Kunak and Lahad Datu (Fig. 3). The FGDs were selected based on whether the communities included either cooperative or individual farmers. SQs were selected using the purposive sampling method from lists supplied by the Sabah Fisheries Department (SFD). Personal observation was used to see at firsthand farmers' facilities and activities either at sea or in their houses. Secondary sources included national seaweed production and trading data published by the SFD and the United Nations International Trade Statistics Database (UN Comtrade 2019).

\section{Data analysis}

The qualitative data obtained from transcripts of KIs, FGDs and personal observations were coded into themes and uploaded into NVivo 11 qualitative research software (QSR International Pty Ltd.). Themes were analysed for connections between data, concepts and theories. The quantitative data obtained from the SQs were processed and analysed as descriptive statistics using the Statistical Package for the Social Sciences (SPSS) version 21 (International Business Machines Corporation). Secondary data (SFD and UN Comtrade) were analysed as descriptive statistics using Microsoft Excel.

\section{Results}

This section is divided into four subsections to reflect each of the four main links in the Malaysian seaweed carrageenan value chain: (1) farming activities, (2) postharvest treatment, (3) marketing and (4) carrageenan processing.
Fig. 3 Map of Malaysia showing Peninsular Malaysia (left), East Malaysia-Sabah (right) and four seaweed-producing towns.

(Source: analysed and processed by the author using the Geographical Information System (GIS) software)

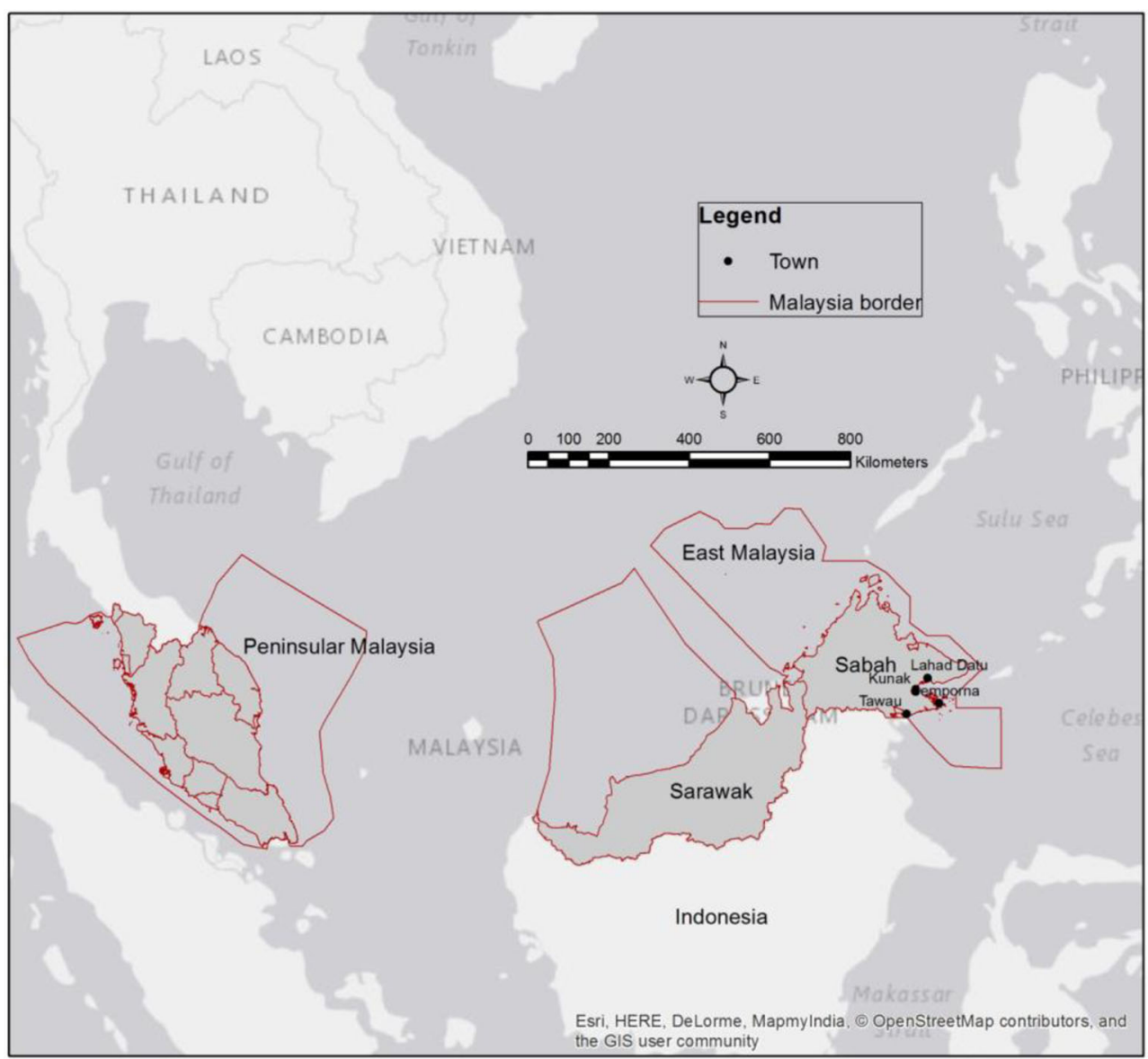




\section{Farming activities}

Farmers procure seedlings as the beginning of farming cycle from trusted sellers such as family members and preferred intermediaries and often from the nearest geographical location to reduce transport costs and stress on the seedlings (seedlings must be transported to the farm site as soon as possible and protected from sun, rain and air). Seedlings are usually transported by boat from the farmers' stilt houses (pondohan) or common platforms to the farming site. During transport, the seedlings are covered with tarpaulins or plastic sheets and wetted with seawater every $15 \mathrm{~min}$. Upon reaching the farm site, the seedlings are immediately placed in seawater and are 'planted' by tying to longlines, often by the farmers and their wives and children (Nor et al. 2017). Planting is the activity when seedlings are tied to longlines. Usually, seedlings are brought from farmers' stilt houses or farmers' common platforms to the farming site by boat. Farmers should not crush or walk on the seedlings while transporting them to the site because it can damage the propagules. After that, farmers with the help of their wives and children will tie the seedlings to those lines under the scorching sun. However, currently (2019) seaweed farmers in Semporna have shortened their farming lines so that the waves would not break the seaweed so easily. Short farming lines also eased farm management and improved production efficiency because the farmers could bring the farming lines to their homes which enable them to perform planting under the shed. Rather than planting the seaweed at the lines under the sun, the short farming lines could be brought to the drying platform, and farmers could plant the seaweed at the planting section on the platform and then place the longlines back to the sea.

Farmers also conducted maintenance work during farming activity. Farmers also conducted maintenance work during farming activity includes the folowwing: repairs of the anchoring system, removing epiphytes and seaweed infected by 'ice-ice', replacing lost and slow-growing seaweed and removal of sediment, rubbish, mud wastes, unwanted weeds and grazers (Uyenco et al. 1981; Vairappan et al. 2008). There are four types of grazing effects: (1) tip nipped (caused by fish, usually adult siganids), (2) pigment picked (caused by juvenile siganids), (3) seaweed are 'planed' leaving a flat surface (caused by sea urchins), and (4) almost the entire seaweed is eaten (by green turtles). Frequent maintenance can increase farm productivity. The seaweed is harvested after 6 to 8 weeks of cultivation. Farmers harvest the whole seaweed either by untying lines or cutting the raffia tie-tie from longlines and transporting them to a stilt house or drying platform. At the platform, the farmers grade the seaweed (known as culling) either to be dried or to be used as seedling material for the next cycle. Farmers immediately replant the new seedlings.

\section{Postharvest treatment}

The seaweeds are sun-dried which takes about 2 to 3 days depending on weather conditions and seaweed density. The commonly used drying methods are spreading the fresh seaweed across concrete slabs or wooden platforms and hanging using elevated drying racks. The seaweed is evenly spread and regularly turned over to expose all angles of the thalli to the sun. Farmers remove further contaminating materials at this stage. Tarpaulins, canvas or plastic sheeting provides protection from rain. The farmer assesses the moisture content by squeezing the seaweed; the desirable moisture content lies between 30 and $38 \%$; the capacity to achieve this is influenced by species, location and the frequency with which farmers turn the seaweed during drying. Well-dried seaweed is heavily covered with crystallised sea salt (Fig. 4), which prevents spoilage of the carrageenan and prolongs storage duration by up to 2 years. The dried product is packed into sacks and stored in a dry ventilated area (generally the farmers' house or work area) before shipment to the buying centre. Whereas a high salt content is desirable for storage purposes, it can affect the quality of carrageenan during processing (e.g. by increasing heavy metal levels (Chan et al. 2013) and can decrease carrageenan yield and gel strength. To combat this, farmers shake or beat the seaweed to reduce the levels of accumulated salt, sand and dirt before sale. Seaweeds are transported to the buying area by boat or truck, during which sheets of plastic are placed on the floor to maintain a dry and clean state.

Although postharvesting activity determines seaweed prices, it was not considered in the SAFA cooperative seaweed development plan:

Our constraint is that we could not build drying platforms for farmers due to a lack of funding and this initiative was not included in our seaweed programme. We found from our farmers that seaweed prices vary between buyers. This is due to a lack of quality control during the drying process by the farmers. That is why in

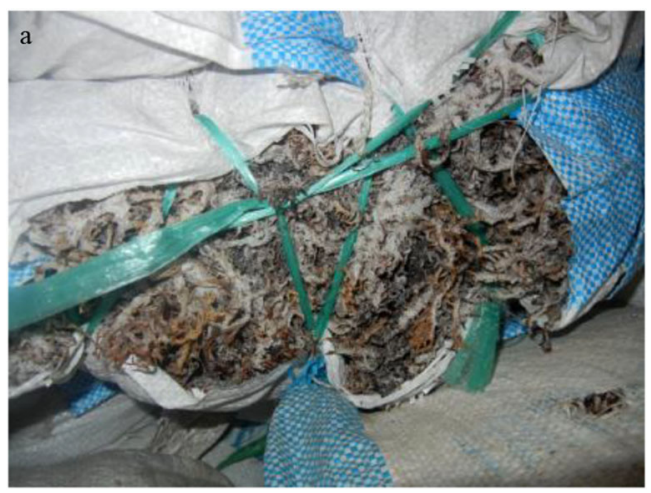

Fig. 4 Dried and packed seaweed covered with crystallised salt 
2010, we managed to secure funding and build a bigger drying platform at our facilities to accommodate wet seaweed bought from the farmers. We have 25 farmers in our seaweed programme, and they worked on an individual basis. They will get help from their own family members. The farmers will schedule their farming and drying activities so that they can use the drying platform according to appropriate capacity. (SAFA Manager KI interview, 14/04/15)

Despite this benchmark for well-dried seaweed, the current practice among processors is to accept moisture content up to a maximum of $50 \%$. If this $50 \%$ standard is not attained, the processor will either import seaweed or will penalise the intermediary through a low pricing structure which is in turn transmitted to the level of the farmer, a situation that is compounded by the farmers' lack of capacity to negotiate which creates a disincentive for farmers to continue production. In such situations, the poor quality unprocessed seaweed is often smuggled to the Philippines; however, some Malaysian processors still prefer to buy from local producers as they can manage the risks of getting poor quality seaweed such as encouraging the use of polyethylene (PE) 'tie-tie' to eliminate raffia 'tie-tie' contamination (Nor et al. 2017).

\section{Marketing systems}

This study found that the SCP cooperatives were ineffectively marketing seaweed for their members. With the exception of the SAFA cooperative, all farmers sold their seaweed to intermediaries who had obtained capital from local processors or Filipino buyers. Brokerage fees (which covered seaweed transportation from sea to the mainland and the workforce costs during loading) were at least $10 \%$ of the seaweed price. The Malaysian Good Aquaculture Practices (MyGAP) seaweed certification programme failed to increase quality and price due to poor awareness of the scheme among the intermediaries who wrongly believed that farmers were continuing to produce poor quality seaweed (Focus Group, 04/06/15). This resulted in farmers being penalised on price. The SCP farmers have limited access to credit for farming activities or daily usage. Although there is a financial institution (i.e. a bank) in the area, the indigenous and SAFA farmers do not use its services, and the migrants are not entitled to access formal financial services. For instance, the SCP cooperatives do not provide credit services, only providing a donation in the event of the death of a family member (SCP Leader LB KI interview, 13/04/15). As a focus group member said, they experienced a 'lack of capital to buy seedlings and other operating costs, and as a result, we cannot increase production' (SCP Gelam-gelam farmers' Focus Group, 02/06/15). The farmers had developed strategies to cope with difficulties in securing capital. For instance, they will borrow seedlings from other farmers and replace or pay once they obtain the money from seaweed sales (SCP Lok Butun farmers' Focus Group, 03/06/15).

Additionally, there is the involvement of the intermediaries in the provision of credit serviced. The role of intermediaries in providing assistance to seaweed farmers remains controversial. Alin and Mahmud (2013) found that farmers and intermediaries maintained good and honest relationships that allowed the farmers to obtain informal credit services either as cash or through the direct supply of farming inputs such as ropes, tie-tie and seedlings. The farmers were also commonly provided with daily need items such as cooking oil, cooking gas cylinders and rice. Their relationships can either be noncontractual, whereby the farmers are not morally bound to intermediaries, or may take the form of an informal obligational buying contract. Generally, intermediaries will not 'steal' farmers who have an informal contract with another intermediary. The farmers called their credit provider intermediaries 'boss' (Fig. 5):

If I deal with collectors who took advance money from other buyers, I will get myself into trouble. They will call me and question why I buy seaweed from their people. The people who gave the capital advance to collectors or farmers are known as boss. (Seaweed buyer $15 \mathrm{KI}$ interview, 12/05/15)

The SAFA farmers obtained the necessary capital from their seaweed sales through the SAFA cooperatives. According to a SAFA manager:

The cooperatives paid between MYR0.20 (US\$0.05) to MYR0.30 (US\$0.07) per kg wet weight which is equivalent to MYR2 (US\$0.46) to MYR3 (US\$0.70) per $\mathrm{kg}$ dry weight with moisture contents between 45 and $50 \%$. This approach has solved the post-harvest process and produced good quality seaweed. The cooperative manages to get a good price from the factory and make a profit. The members are happy and are motivated by this approach. The manager said they have to manage the farmers and provide assistance such as providing farming area and inputs because they are not sufficiently educated to obtain financial support from the bank. (SAFA Manager KI interview, 14/04/15)

Buyers prefer to purchase seaweed directly from farmers they trust that produce large quantities and those residing nearby on the mainland with ease of access for transporting the seaweed. Four seaweed communities-Lok Butun, Gelamgelam, Patuit and Sebangkat—sold seaweed directly to the buyers through both noncontractual and informal contractual relationships because these areas are located near the 
Fig. 5 The relationship between seaweed intermediaries/buyers, i.e. 'boss', and seaweed farmers 'penanam'. (Source: field observation and key informant interviews and after Zamroni and Yamao (2012))

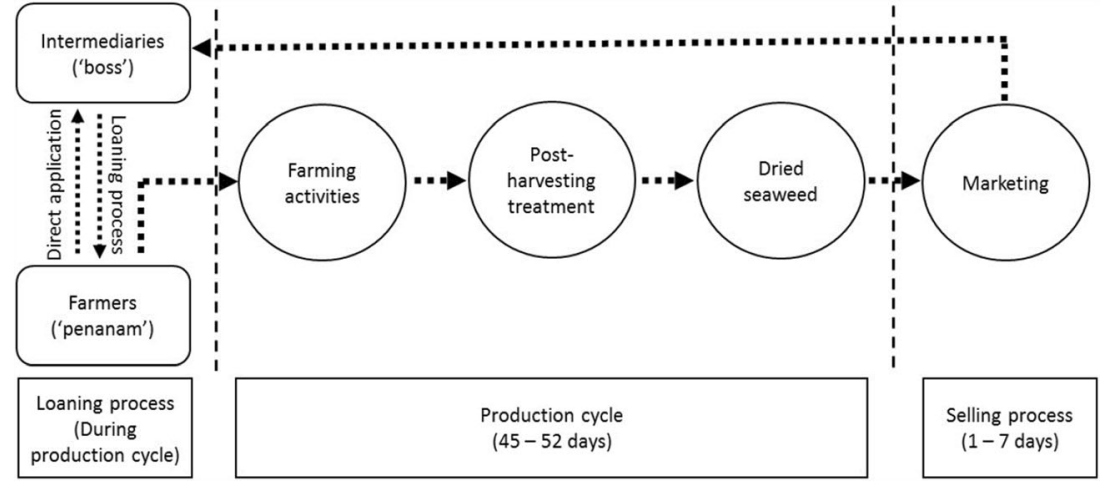

mainland and are less difficult for the boats to manoeuvre around compared to other remote islands. SCP farmers are supposed to sell seaweed to the SCP cooperative; however, the farmers often chose to sell to another buyer as the cooperative did not guarantee to buy. According to an SCP leader, 'at the moment, I act as a seaweed buyer and offer them my price. Some will sell to me, and some will sell to other buyers. I am confused with the SCP because the government did not assist in marketing for such mega projects'. In contrast, Gelamgelam SCP farmers' Focus Group, 02/06/15 responded 'we have our own organisation (SCP cooperatives) but they just use our name to get assistance from the government. We did not benefit from the organisation. The cooperative did not buy our seaweed. We have to sell on our own'. The SCP farmers had no other option but to sell their seaweed to the intermediaries who came to the island. The cooperative members in Mata Pahi and Melanta Kobal had an informal contract with the SAFA because they received assistance such as permission to use SAFA farming areas, farming inputs and training and marketing outlets. SAFA bought wet seaweed from the members and dried the seaweed using the SAFA drying platform located near to the farming areas:

We collaborate with farmers whereby we provide farming area and inputs, but the farmers have to sell their wet seaweed to us at an agreeable price. The reason we buy wet seaweed is that most of the farmers do not have a drying platform. Before this programme, they could not sell their seaweed because they cannot dry it and their seaweed spoiled and rotted. The lack of seedlings is one of the factors why farmers could not sustain their farming activity. We provided seedlings for the first farming cycle, and after that the farmers have to produce their own seedlings. Before this, they sold all their wet seaweed as seedlings because the price was high. (SAFA Manager KI interview, 14/04/15)

However, Norazah et al. (2013) highlighted that this relationship isolated the farmers wherein the intermediaries were their only available marketing channels, potentially allowing them to be exploited by the price-setting processors. There were at least two or three layers of intermediaries before the seaweed was sold to the processors. Local production exceeded $2000 \mathrm{t}$ of dried seaweed per month, of which the local processors (three carrageenan factories) typically bought 10-50\% - this proportion is influenced by global carrageenan demand (with an average annual growth rate of $2 \%$ (Panlibuton et al. (2007)).

The status (as illegal immigrants or war refugees) of the Filipino farmers prevents them from accessing government aid. Consequently, they have developed a system of informal contracts for credit services and assistance with the intermediaries. The intermediaries prefer to not buy from the SCP or local farmers unless they were unable to obtain adequate dried seaweed supply from the Filipino farmers. The intermediaries perceived that the local farmers were inactive and ineffective farmers (ABI KI interview, 16/06/15). According to ABI KI interview, 16/06/15, 'the local farmers were usually laid back and became lazy. They are always waiting for the governments' assistance or subsidy'. Seaweed buyer $9 \mathrm{KI}$ interview, 21/05/15 said: 'I did not buy seaweed from farmers under government projects because their production is low'. The intermediaries obtained seaweed from the most productive areas such as Sibuan, Sangaban, Omadal and Sebangkat. Seaweed buyer $9 \mathrm{KI}$ interview, 21/05/15 said, 'I always bought from pondohan Sibuan farmers because seaweed production is high in this area'. Another intermediary, Seaweed buyer $10 \mathrm{KI}$ interview, 02/05/15, said there were 'only a few farming sites (Sangaban and Omadal) which produce good quality seaweed with low moisture content and free from raffia tie-tie'. In addition, Seaweed buyer $12 \mathrm{KI}$ interviews, 21/ 05/15, said, 'I have my people in pondohan Sibuan, Sebangkat and Silungun. I give them money because they are my friends and I trust them'. The intermediaries preferred to smuggle the surplus seaweed to the Philippines as the Filipino buyers were less stringent over quality. The role of intermediaries in the seaweed value chain is therefore good for the migrant and indigenous farmers in that they provide informal credit services and market access, but bad in that they 
have a monopoly on demand and can set their own price for local seaweed. SAFA cooperatives only buy seaweed from their own members because the demand from local carrageenan processors is limited.

\section{Carrageenan processing}

Demand for Malaysian seaweed carrageenan increased in response to the establishment of the two local carrageenan processing factories (Tacara and Omnigel) in Sabah. Tacara produced ATC and SRC food grade, while Omnigel processed seaweed into ATC and SRC nonfood grade. In 2010, Lucky Frontier Sdn. Bhd. (Lucky Frontier) was established in Kunak, which is located $50 \mathrm{~km}$ from Semporna town. Lucky Frontier became the first processing factory that produced both RC and food grade SRC. All carrageenan processors prioritised their agents because the agents supplied good quality seaweed and there is a trust relationship between the processors and agents. In order to obtain a consistent supply, the companies hired their agents by providing them with a boat and capital to buy the seaweed. In total, the carrageenan processing factories have a processing capacity of $4000 \mathrm{t}$ annually, producing ATC, SRC and RC. Based on current carrageenan processing capacity, all processors required between 12,000 and $20,000 \mathrm{t}$ of dried seaweed to produce $4000 \mathrm{t}$ of carrageenan annually. In 2014, carrageenan exports remained at just over 1000 t. Despite this, Malaysia exported less than $1 \%$ of legal global dried seaweed and slightly over $2 \%$ of the world carrageenan supplies despite the export price (due to compliance with international standards) being higher than the local price (Table 2). The farmers could not switch to processing as the required investment is too high (investment for a cosmetic processing plant is around US\$ 200,000 and requires certification). Nonfood grade carrageenan does not require certification, but the price is low. However, a local company has a processing plant for food grade in China as part of their business model.

Table 2 Price determination based on quality at different marketing levels

\begin{tabular}{lll}
\hline Marketing level & $\begin{array}{l}\text { Dried seaweed } \\
\text { price (US\$ kg }\end{array}$ & $\begin{array}{l}\text { Range of quality (using } \\
\% \text { moisture content as } \\
\text { the main quality criterion) }\end{array}$ \\
\hline Farm gate & 0.58 & $39-82^{*}$ \\
Local processor & 0.77 & Maximum 50\%** \\
Export price & 1.14 & Maximum 40\%** \\
\hline
\end{tabular}

*Value based on the moisture content analysis 2013 report of local carrageenan processors

**Value based on key informant interviews during fieldwork in 2015

\section{Discussion}

\section{Migrant farmers}

On the question of migrants, this study found that the Malaysian government has a serious problem of how to deal with Filipino migrants who are energetic seaweed farmers but whose legal status is uncertain. Historically, the Moro conflict in the southern Philippines forced more than 50,000 people to migrate to Sabah in the 1970s (UNHCR, 2015). In the late 1980s, the Malaysian government divided the Filipino migrants into three categories: illegal migrants, war refugees and economic migrants (Kassim, 2009). Migrant farmers consisted of these three categories, and seaweed farming became a safety net for their communities who have been living in pondohan stilt huts. Although official data on the number of migrant farmers are unavailable, it is estimated that the migrant farmers contributed more than half of total national seaweed - around 20,000 to $30,000 \mathrm{t}$ - between 2010 and 2015. Because they are not Malaysian citizens, these migrants are not eligible to join the SCP, and therefore they are unlikely to be able to scale up their seaweed farming operations to the commercial scale desired by the government. The migrant farmers get assistance from the buyers because majority of buyers are from the Suluk ethnicity, and they perceived that it is their obligation to help the migrants because of the marginalisation by the government towards them. Usually, the migrant farmers owned a small drying platform, and they are more active than local farmers, and they rely on the intermediaries to buy their produce and provide informal credit services. Some local farmers who inherited the farms through social norms leased out their farm to migrants or hired them to work on their farms because of lack of manpower in this sector (Bahron, 2013; Eranza et al. 2015).

\section{Price volatility}

As previously mentioned, price volatility is an important disincentive for potential SCP farmers. In 2008, the 'seaweed crisis/price bubble' caused by 'campaign buying' among Chinese buyers affected the global seaweed carrageenan industry (Bixler and Porse 2010). The global export price of dried seaweed increased between 2000 and 2009 from less than US $\$ 1.00 \mathrm{~kg}^{-1}$ to US $\$ 2.30 \mathrm{~kg}^{-1}$. Farmers rushed to harvest premature seaweed during this period, resulting in low-quality raw materials flooding the market. The export price of dried seaweed was less volatile before the 'seaweed crisis' and has remained volatile since (Neish 2008, 2013). At the time of this study (2015), Malaysia was the third largest global seaweed carrageenan producer (Valderrama et al. 2013). The Philippines was the major market for Malaysian raw materials from 2012 to 2013 (68 to $76 \%$ of total export). However, China took over as the major seaweed buyer and imported more than 60\% from 2014 until the time of writing (Royal 
Malaysian Customs Department, unpublished data). The highest export level was achieved in 2009 (1290 t). This study found that the local seaweed prices were determined by the processors and intermediaries. Another important finding was that the average local price was lower than the export price. In this study, the buyers complained that local farmers did not produce enough quantity to satisfy processing demand and causing them to import the raw material. Numerous problems relate to the short period of the high demand for raw material.

\section{Marketing system}

The weak market mechanism has contributed to economic volatility in the seaweed sector. The Malaysian government has not intervened directly to reduce price volatility, although it has tried to strengthen the seaweed marketing system by forming farmers' organisations and establishing a seaweed certification programme. However, the effectiveness of these efforts is in doubt, and they do not address the main problem of price fluctuation. More recently, the Minister of Agriculture and Agrobased Industry has given the Federal Agricultural Marketing Agency (the parastatal at the federal level responsible for food and agricultural marketing roles) responsibility for overcoming seaweed marketing problems in Semporna. However, the processors said the government agencies did not know how to deal with the marketing issue. Although several KIs expected the seaweed industry to expand and develop through government intervention and global demand from the processed food industry, respondents identified many problems with marketing. The seaweed marketing system was disorganised and unstructured because buyers did not feel any obligation to report or deal with the responsible agency, i.e. the Sabah Fisheries Department. All they needed was a trading licence from the district office and a seafood trading permit from the Fisheries Development Authority of Malaysia (FDAM) [neither agencies were responsible directly for the management of the seaweed industry]. Furthermore, there were gaps and poor communications between the buyers and the responsible agency, which was why data on marketing, production and smuggling were scarce. This research suggested that the local seaweed cooperative organisations should be strengthened so that these organisations could provide a platform for farmers, buyers and processors to address seaweed-related issues. The cooperatives could also provide services and become a business network for members. Moreover, the government should teach entrepreneurship skills to farmers so that they may negotiate with buyers and find other market outlets, thus making farmers more independent.

\section{Seaweed quality}

The current study found that another challenge to the Malaysian government's objective of turning the country's seaweed farming industry into a major world player is the poor quality of much of the seaweed produced. The quality of the seaweed, and in particular the drying process, determines the quality (and ultimately the value) of the end product (Neish, 2013). This directly impacts on the Malaysian government's objective of further expanding the seaweed farming industry. The production of high-quality dried seaweed can be achieved if the farmers practise good drying techniques. The important seaweed quality issues at the processing level were moisture content, seaweed maturity and impurities. Seaweed should be harvested after 45 days or 7 weeks of the farming cycle and should be cleaned from raffia or 'tie-tie' ropes, unwanted algae and silt. The current practice among processors is to reduce the moisture content to a maximum of $50 \%$. One unanticipated finding was that to get this quality (an average of 50\% MC level), processors penalised intermediaries and intermediaries penalised farmers, so farmers were offered a low price as they did not have the capability to negotiate. This is a severe disincentive for farmers to continue production, and the processors will import seaweed if there is insufficient quality local supply.

Table 3 The current state and way forward of the critical success factors

\begin{tabular}{|c|c|c|}
\hline Critical success factors & Current state & Way forward \\
\hline 1) Quantity (sufficient dried seaweed supply) & $\begin{array}{l}\text { Low quantity and inconsistent supply } \\
\text { due to limited drying space }\end{array}$ & $\begin{array}{l}\text { Provide credit scheme or loan to } \\
\text { upgrade their drying facilities }\end{array}$ \\
\hline 2) Moisture content & $\begin{array}{l}\text { Majority of farmers produced dried } \\
\text { seaweed with more than } 40 \% \\
\text { moisture content through } \\
\text { unpredictable weather and lack } \\
\text { of awareness of quality criteria }\end{array}$ & $\begin{array}{l}\text { Provide training on drying technology. } \\
\text { Encourage participation in seaweed } \\
\text { certification scheme }\end{array}$ \\
\hline 3) Quality (eliminate foreign matter contamination) & Lack of awareness of quality standards & $\begin{array}{l}\text { Encourage participation in seaweed } \\
\text { certification scheme }\end{array}$ \\
\hline 4) Promotion desirable seaweed properties, e.g. colour & $\begin{array}{l}\text { Harvesting immature seaweed and } \\
\text { using poor dying technique }\end{array}$ & $\begin{array}{l}\text { Encourage participation in seaweed } \\
\text { certification scheme }\end{array}$ \\
\hline 5) Appropriate and stable pricing & Seaweed price is volatile & Improve marketing mechanisms \\
\hline
\end{tabular}




\section{Conclusion}

This research set out to evaluate the Malaysian seaweed sector by using value chain analysis (VCA) to identify and understand the weaknesses of seaweed policy and finally made some recommendations for the national seaweed policy. A key finding was that economic constraints affected seaweed stakeholders at different levels: farmers, private and government. The SCP farmers were unable to produce seaweeds as targeted because of poor farming effort and low farm-gate prices. Private groups such as intermediaries were dominated by the migrant ethnicity and were able to monopolise seaweed prices as they provided informal credit services to the farmers. The price of seaweed is volatile, with the farm-gate price varying every 2 weeks, sometimes every week. The farmers do not sell directly to the processors as they have poor marketing networks and are forced to rely on intermediaries, who usually arrange the transport from the farmers to the mainland. The weak negotiating position of the farmers in the value chain serves to perpetuate their low-income status. The SCP cooperative system was unable to replace the intermediaries' role in providing such services, and this forced the SCP farmers to sell seaweed to intermediaries and get penalised for poor quality despite the SCP farmers being certified under the MyGAP programme. The farmers did not perceive that producing high-quality seaweed would result in higher prices. Thus, they still produced low-quality seaweed. This programme should be revitalised in order to meet with local and international requirements. To achieve this, the government should increase their efforts in monitoring and provide more training among seaweed certification participants. There was low trust in relationships between processors, intermediaries and farmers on seaweed quality, which resulted in the farmers being penalised. This barrier could be solved by adopting seaweed standard guidelines enforced by the authority. The SCP system was unable to improve the economic prospects of seaweed and private investment due to weak market mechanisms, low global demand for carrageenan and limited markets for new seaweed-based products. The limited dried seaweed and carrageenan export volume and a small contribution to gross domestic product (GDP) resulted in low prioritisation to develop this sector at the government's level.

The seaweed marketing system was dominated by the intermediaries who smuggled the seaweed to the southern Philippines. The majority of intermediaries were from Filipino migrant ethnicity and encouraged the migrant farmers to continue farming all year round by providing informal credit services. The migrant farmers were the most successful seaweed producers even though they were marginalised. Although their income from seaweed farming was higher than the SCP farmers and above the national poverty line, they were not entitled to deal with formal banking institutions. Finally, the government should strengthen the marketing mechanisms by focusing on critical success factors for dried seaweed: (1) ensuring sufficient supply; (2) enabling farmers to produce seaweed with low moisture content (3) and with minimal foreign matter contamination; (4) promoting the desirable seaweed properties, e.g. colour and quality; and (5) enabling appropriate and stable pricing structures (Table 3). Such steps could transform the prospects for seaweed production in Malaysia. Similar approaches to study the seaweed value chain have been undertaken in Indonesia and the Philippines (Andriesse and Lee 2017; Ferdinandus et al. 2017; Mulyati and Geldermann 2017), the two largest seaweed carrageenan-producing nations. It is hoped that a similar approach can support the sustainable growth of the seaweed industry in Malaysia.

Acknowledgements The authors thank the Economic Planning Unit, Prime Minister's Department Malaysia, Department of Fisheries Malaysia and Sabah Fisheries Department for granting permission to conduct this fieldwork, and the seaweed communities in Semporna, community leaders, government officials, NGOs, carrageenan processors and villagers for their kindness, cooperation and hospitality. We also thank Dr James Alin, Ms Nazmahwati Walli and Mr Mizpal Ali of Universiti Malaysia Sabah (UMS) for assistance during fieldwork, and Mr Masri Bangkoka of Gelam-gelam village for assisting with community assimilation. Any shortcomings of the paper belong to the authors.

Funding information This work was funded by the Government of Malaysia, Newcastle University, UK, and was part of Global Seaweed STAR project supported by the Global Challenge Research Fund (GCRF).

\section{Compliance with ethical standards}

Ethics statement This study received ethical approval from the Newcastle University Ethics Committee. Additional permissions were granted by the Malaysian government (Economic Planning Unit, Prime Minister's Department).

Open Access This article is distributed under the terms of the Creative Commons Attribution 4.0 International License (http:// creativecommons.org/licenses/by/4.0/), which permits unrestricted use, distribution, and reproduction in any medium, provided you give appropriate credit to the original author(s) and the source, provide a link to the Creative Commons license, and indicate if changes were made.

\section{References}

Alin JM, Mahmud R (2013) Trusting each other? Seaweed farmers and middlemen in Semporna Islands, Sabah. In: 21st International Seaweed Symposium, Bali, Indonesia, 21 - 26 April 2013. p 55

Andriesse E, Lee Z (2017) Viable insertion in agribusiness value chains? Seaweed farming after typhoon Yolanda (Haiyan) in Iloilo Province, the Philippines. Singapore J Trop Geogr 38:25-40

C A (2013) Issues and challenges in the seaweed industry in Sabah at micro and macro levels. 21st International Seaweed Symposium. Bali, Indonesia, 21-26 April 
Bixler HJ, Porse H (2010) A decade of change in the seaweed hydrocolloids industry. J Appl Phycol 23:321-335

Bjerregaard R, Valderrama D, Radulovich R, Diana J, Capron M, Mckinnie CA, Cedric M, Hopkins K, Yarish C, Goudey C, Forster J (2016) Seaweed aquaculture for food security, income generation and environmental health in tropical developing countries. World Bank Group, Washington, D.C.

Chan SW, Mirhosseini H, Taip FS, Ling TC, Tan CP (2013) Comparative study on the physicochemical properties of $\mathrm{K}$-carrageenan extracted from Kappaphycus alvarezii (doty) doty ex Silva in Tawau, Sabah, Malaysia and commercial K-carrageenans. Food Hydrocoll 30:581588

DOFM (2019) Portal Rasmi Jabatan Perikanan. Department of Fisheries Malaysia. https://www.dof.gov.my/index.php/pages/view/307

Eranza DRD, Bahron A, Alin J (2015) 'Sustaining seaweed farming in Malaysia', The International Journal of Business \& Management, 3(3):201

FAO (2016) The State of World Fisheries and Aquaculture 2016. Contributing to food security and nutrition for all. Rome. 200 pp 200

Ferdinandus SJ, Risambessy A, Sormin RBD (2017) Strategy for increasing added value by seaweed processing and marketing business (a case study in west Maluku Tenggara Regency-Indonesia). Man in India 97:439-447

Ferdouse F, Yang Z, Løvstad Holdt S, Murúa P, Smith R. (2018). The global status of seaweed production, trade and utilization. Rome, Italy: FAO Globefish.

Kassim A (2009) Filipino refugees in Sabah: State responses, public stereotypes and the dilemma over their future. Southeast Asian Studies 47:52-88

Li L, Ni R, Shao Y, Mao S (2014) Carrageenan and its applications in drug delivery. Carbohydr Polym 103:1-11

McHugh DJ (2003) A guide to the seaweed industry. FAO Fisheries Technical Paper 441. Food and Agriculture Organization of the United Nations, Rome

Mulyati H, Geldermann J (2017) Managing risks in the Indonesian seaweed supply chain. Clean Technol Environ Policy 19:175-189

Neish IC (2008) Structure and development of tropical red seaweed value chains with focus on the red algal galactan seaplants (RAGS), SEAPlant.net Monograph No. HB2A 0808 V1.

Neish IC (2013) Socio-economic dimensions of seaweed farming in Indonesia - full version. Monograph No. SATOUMI_SED_20SEP13.

Nor AM, Gray TS, Caldwell GS, Stead SM (2017) Is a cooperative approach to seaweed farming effectual? An analysis of the seaweed cluster project (SCP), Malaysia. J Appl Phycol 29:2323-2337

Norazah MS, Amran H, Oswald I, Zainul J (2013) An exploratory study on product, price, distribution channels, and promotion of seaweeds in Semporna district of Sabah, Malaysia. Labuan e-Journal of Muamalat and Society 7:28-32
Panlibuton H, Porse H, Nadela E (2007) Seaweed/carrageenan value chain assessment. Seaplant.net initiative of IFC Advisory Services and GTZ Philippines. pp 47, Manila

PEMANDU (2013) 'ETP Annual Report 2013'. Available at: http://etp. pemandu.gov.my/annualreport2013/ (Accessed: 22 February 2017). Jabatan Perdana Menteri

Phang SM, Yeong HY, Lim PE (2019) The seaweed resources of Malaysia. Bot Mar 62:265-273

Porse H, Rudolph B (2017) The seaweed hydrocolloid industry: 2016 updates, requirements, and outlook. J Appl Phycol 29:2187-2200

Prajapati VD, Maheriya PM, Jani GK, Solanki HK (2014) Carrageenan: a natural seaweed polysaccharide and its applications. Carbohydr Polym 105:97-112

Sievanen L, Crawford B, Pollnac R, Lowe C (2005) Weeding through assumptions of livelihood approaches in ICM: seaweed farming in the Philippines and Indonesia. Ocean Coastal Manage 48:297-313

Siew-Moi P, Hui-Yin Y, Hussin H, Phaik-Eem L, Hack-Churl Y, JoonChing J (2017) Techno-economics of seaweed farming along the coasts of Kelantan, east coast peninsular Malaysia. Malays J Sci $36: 85-102$

Teh E (2012) Fisheries in Malaysia: Can resources match demand? Sea Views, vol 10/2012. MIMA, Kuala Lumpur https://comtrade.un. org/ (2019)

UNHCR (2015) Refugee Factsheet Malaysia. United Nations High Commissioner for Refugees, Kuala Lumpur. Available at: http:// www.unhcr.org/56167f6b6.pdf. Accessed 15 Jan 2016

Uyenco FR, Saniel LS, Jacinto GS (1981). The "ice-ice" Problem in Seaweed Farming. In Tore Levrig (Editor), International Seaweed Symposium (Xth): Proceedings, Göteborg, Sweden, August 11-15, 1980, pp. 625-630. Berlin, Boston: De Gruyter

Vairappan CS, Chung CS, Hurtado AQ, Soya FE, Lhonneur GB, Critchley A (2008) Distribution and symptoms of epiphyte infection in major carrageenophyte-producing farms. Journal of Applied Phycology 20:477-483

Valderrama D, Cai J, Hishamunda N, Ridler N (2013) Social and economic dimensions of carrageenan seaweed farming. Fisheries and Aquaculture Technical Paper, vol 580. FAO, Rome, p 204

Wood E, Davies A (2006) Semporna Islands Darwin Project 2005 - 2008 : Alternative livelihoods. Sabah Parks. http://www. sempornaislandsproject.com/pages/darwin/alternative.htm Accessed 16 October 20142014

Zamroni A, Yamao M (2012) An assessment of farm-to-market link of Indonesian dried seaweeds: Contribution of middlemen toward sustainable livelihood of small-scale fishermen in Laikang Bay. Afr J Ag Res 7:4198-4208

Publisher's note Springer Nature remains neutral with regard to jurisdictional claims in published maps and institutional affiliations. 